\title{
Frequency and variation of three-rooted lower first permanent molars in precontact Easter Islanders and in Pre-Conquest Peruvians
}

\author{
Andrea G. Drusini ${ }^{1 *}$ and Daris R. Swindler ${ }^{2}$ \\ ${ }^{1}$ University of Padova, Italy and ${ }^{2}$ University of Washington, Seattle, Washington
}

ABSTRACT The purpose of this study was to evaluate the prevalence of mandibular first molars featuring a distolingual root in two archeological collections. A total of 172 teeth from Pre-Contact Easter Islanders and 281 teeth from three Pre-Conquest Peruvian sites were examined looking for the presence of three-rooted lower first permanent molars (3RLM1). The Easter Island teeth were recovered during the Ahu Tongariki excavation Project 1993-2001: we identified 70 M1s, 62 M2s and $40 \mathrm{M} 3 \mathrm{~s}$. The sample contained 20 lower molars with an extra root, meaning that there is $29 \%$ with 3RLM1. The Peruvian teeth are from three archeological sites: Nasca (Proyecto Nasca, $n=100$ ), Arequipa (Proyecto

Three-rooted mandibular first molars were, as far as we know, first described in England by A. E. Taylor (1899). Since then, investigators have reported 3RM1 in various frequencies in human populations, and it was noticed that 3RM1 was higher in most Asian populations (Tratman, 1938, 1950; Pederson, 1949; Turner, 1971; Loh, 1990; Ming Gene Tu et al., 2007). In a worldwide survey of 11,318 individuals from 286 prehistoric skeletal and recent populations, Turner and Benjamin (n.d.) found 3RM1 most common in Asian and Asian-derived populations, especially in the Arctic and North Asian populations (ca. 25-30\%) and least common (ca 1\%) in European and African groups. It should be noted, however, that their survey included only one sample of Africans south of the Sahara. In Polynesia, the average is about $8.5 \%$ while the world average is approximately $10 \%$. This paper deals with two teeth samples, one from Polynesia (Easter Island) and one from Peru: the aim of the study is to offer a contribution concerning the three-rooted mandibular first molars frequency and distribution.

Easter Island is one of the world's most isolated inhabited islands. Human penetration into the Pacific commenced about 60,000 to 45,000 years ago when humans reached Australia and crossed the land bridge connecting Queensland Australia to New Guinea (Green, 1991). Easter Island (Rapa Nui; Fig. 1) is in an extreme windward position as the easternmost of
Condesuyos, $\mathrm{n}=28$ ), and Tablada de Lurín (Proyecto Loma de Lesix, $n=153$ ). We found $8 \%$ of 3RLM1 at Nasca, $1.2 \%$ at Tablada de Lurín, and 9\% at Condesuyos (total frequency $=6 \%$ ). The percentage of 3RLM1 in Easter Island, very high compared to the whole Polynesia and the Peruvian sample, shows the effect of a genetic bottleneck (accidental reduction of a population), which the settlers went through as they reached the island they named Rapa Nui. We conclude that founder effect and genetic drift have played an important role in regulating the past and present mosaic distribution of 3RLM1 in insular populations. Dental Anthropology 2009;22(2):1-6.

some 287 islands forming the cultural entity known as Polynesia. Easter Island has an area of only 64 square miles and is rather triangular in shape. It is situated in the Southern Hemisphere at $27^{\circ} 9^{\prime}$ south latitude and $109^{\circ}$ $26^{\prime}$ west longitude, about 2,300 miles west of Chile and some 1,400 miles east of Pitcairn, the nearest inhabited island. The original Easter Islanders are believed to have been Polynesians ultimately derived from Asia who spoke a Austronesian language, specifically an eastern Polynesian dialect related to Hawaiian and Marquesan. Indeed, Captain James Cook recognized that the Easter Islanders spoke the Polynesian language when he visited the island in 1774. Human penetration into the Pacific had commenced by about 60,000 to 50,000 years ago when humans reached Australia, and it appears that New Guinea has been occupied for at least 40,000 years. Many islands of the Western Pacific (Near Oceania), however, have been inhabited less than 5,000 years while those in the Central and Eastern Pacific (Remote Oceania) have been occupied for less than a 1,000 years. It now appears that the Polynesian islands were populated by what is called the Ancestral Polynesian Society, which, in turn, was part of the Eastern division

\footnotetext{
*Correspondence to: Andrea G. Drusini, Department of Medical-Diagnostic Sciences and Special Therapies, University of Padova Via Giustiniani, 2, Italy

E-mail: andrea.drusini@gmail.com
} 


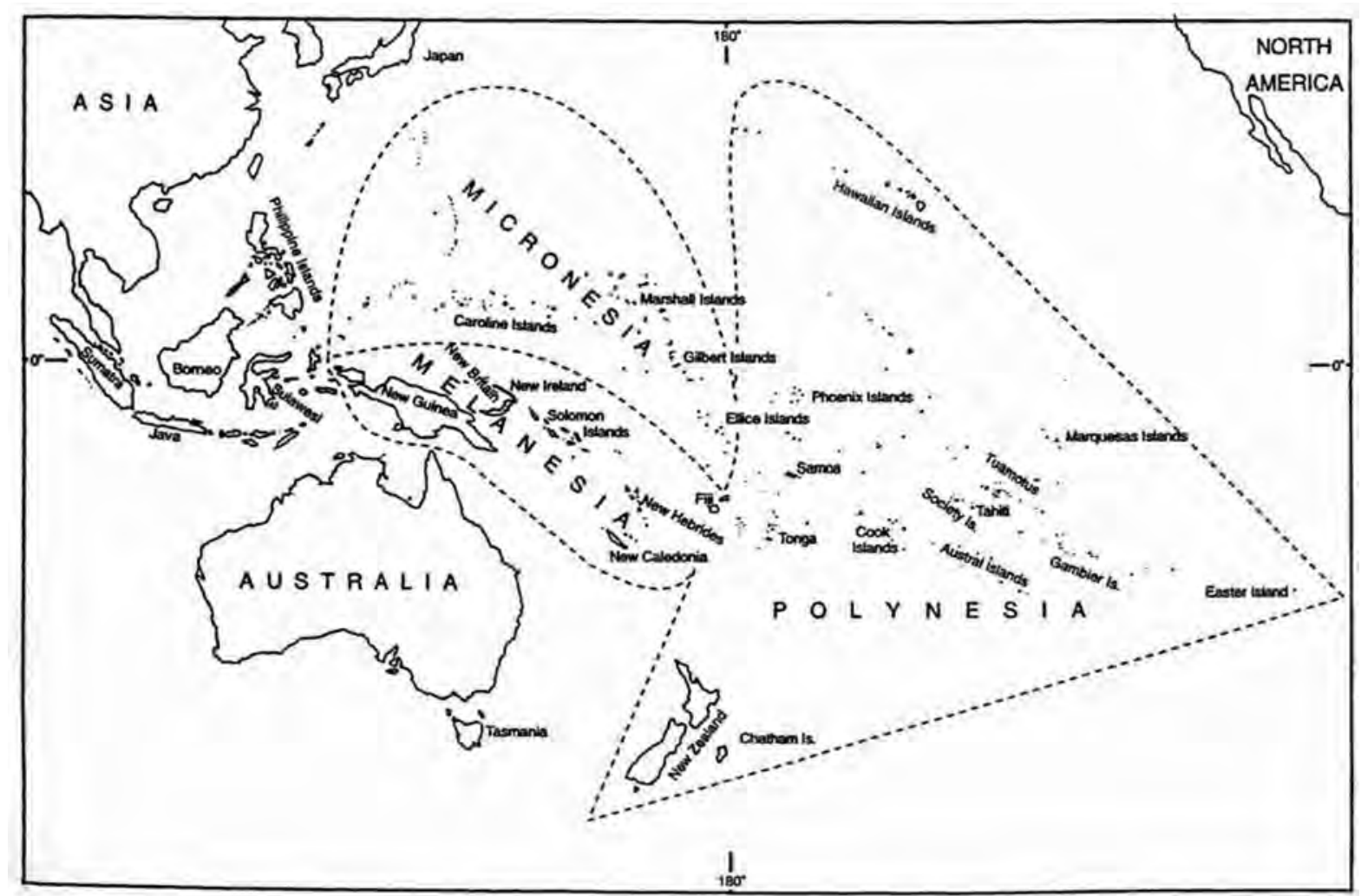

Fig. 1. Easter Island located at an extreme windward position in the Pacific.

of the Lapita Cultural Complex (Kirch, 1984; Van Tilburg, 1994). There is good evidence that these Austronesian speaking people had started moving out of Southeast Asia by about 3,000 BC, and interestingly, there is still a genetic link (deletion of a short section of the DNA in the mitochondria, or mtDNA) between the Polynesians of today and Southeast Asian populations (Jones, 1994). The nucleus of the Ancestral Polynesian Society was settled in the Fiji-Samoa-Tonga region of Western Polynesia by about 1,500 BC. From here the more eastern Polynesian Islands were gradually colonized. Easter Island, the easternmost of the islands of Polynesia, was settled near the end of the first millennium $\mathrm{AD}$, probably between 400 and 800 AD (Van Tilburg, 1994; see also Bellwood 1987; Bahn, 1993; Bahn and Flenley, 1992). Finney (1993) has suggested three possible settlement routes based on seasonal patterns of winds, currents, and weather conditions. Route 1 is from the Marquesas and would have required an El Niño with westerly winds. Route 2 is from the Tuamotus/Mangareva islands and would have been undertaken during a period of winter westerlies. Route 3 is the most southerly route and comes through the Australs via Rapa to Easter Island. (Note: westerlies are more common below $30^{\circ}$ south latitude). It is not certain which of these routes was used or, in addition, whether there was a single or multiple migrations. Van Tilburg (1994) says that some Easter Island traditions suggest two early migrations but there is no indication as to the amount of time separating them. Rapa Nui tradition, although undoubtedly limited in its usefulness, states that there were probably two canoes carrying the original settlers with anywhere from 25 to 100 people aboard (Van Tilburg, 1994). It is also speculated that the party was composed of related individuals of various ranks and abilities and that they landed in the vicinity of Anakena on the north central coast of Easter Island, probably sometime between 600 and 800 AD (Van Tilburg, 1994).

This pattern of migration has probably characterized the peopling of the Pacific islands for the last 5,000 years, i.e., relatively small groups of individual representing various degrees of genetic relationships, particularly in Polynesia. Where descent-groups are never completely exogamous, genetic affiliations may have been rather closeamong the members of a migrating group. Of course, all voyages were unplanned for there were certainly accidental, unintentional migrations of individuals blown into unknown seas who happened to land on an island with only their genomes. Such migration patterns are ideal for the operation of the founder effect, genetic bottlenecks, and genetic drift. The percentage of 3RLM1 in Easter Island, very high compared to the whole of Polynesia and our Peruvian sample, shows the effect of a genetic bottleneck (accidental reduction of a population), which the settlers went through as they reached the island they named Rapa Nui. Founder effect 
and genetic drift seem to have played an important role in regulating the past and present mosaic distribution of 3RLM1 in insular populations.

\section{MATERIALS AND METHODS}

In 1993, during the Ahu Tongariki excavation directed by Claudio Critino and co-directed by Giuseppe Orefici, the molars that form the basis of this investigation were collected (Orefici and Drusini, 1993). The Ahu Tongariki is situated on the southeastern coast of the island. The human skeletal remains of the Tongariki 14548 site were found scattered in an area of some 5,000 square meters. The skeletons were mostly incomplete and fragmented, the bone tissue was generally dry and brittle, and the in situ physicochemical erosion had given the periosteal surface a heavily weathered appearance. Only the teeth were in a fairly good condition. The bone assemblage was always related to collective secondary burials of pre-contact islanders (before 1,722 according to preliminary $\mathrm{C}^{14}$ dating). Since the reconstruction of individual skeletal complexes was impossible, the analysis was performed on the isolated bones and teeth. While examining these teeth we noticed that several of the lower molars possessed three roots rather than the usual two roots. In view of the prevalence of threerooted lower first permanent molars (3RM1) in Asian populations we thought it would be of anthropological interest to review the pattern of 3RMls in the Pacific islands and determine if there is a west-to-east cline in their distribution, and attempt an explanation for the rather high incidence of 3RMls in pre-contact Easter Islanders.

Human lower molars usually have two roots, one mesially and one distally placed transversely to the mesiodistal length of the tooth crown. The roots of the second and third molars are more variable in length and inclination than those of the first molar. Additionally, the roots of the second and third molars may fuse together, especially those of the third molar, which may also have more than two roots. Crown size, morphology, contact areas, and root anatomy were used in identifying the molars. There were 172 permanent lower molars consisting of $\mathrm{Ml}=70, \mathrm{M} 2=62$, and $\mathrm{M} 3$ $=40$. We tried to be as careful and accurate as possible in identifying the lower molars as to M1, M2 or M3 but some misidentifications are always possible when dealing with isolated teeth, especially between M1 and M2.

The second sample of teeth belongs to three archeological sites of Peru: Nasca, South Coast of Peru (Proyecto Nasca, $\mathrm{n}=100$ ), Arequipa (Proyecto Condesuyos, $\mathrm{n}=28$ ), and Tablada de Lurín (Proyecto Loma de Lesix, $n=153$ ). As far as the Nasca Project is concerned, the study was based on skeletons and mummies belonging to 582 individuals excavated at sites of Pueblo Viejo, Cahuachi, Estaqueria and Atarco in the Nasca valley, South Coast of Peru. Archaeological evidence distinguishes three cultural phases: Nasca (400 BC-550 AD), Wari (600-1100 AD) and Chincha (11001412 AD). Since the Chincha human remains were too exiguous (27 individuals), only Nasca and Wari were considered. For the Nasca population, sex ratio was 113 men to 100 women ( $53 \%$ males); for the Wari population, sex ratio was 117 men to 100 women (54\% males). Life tables with zero growth and with a natural increase of $2.5 \%$ per year were created. Paleodemographic data show that first infancy was a critical age for survival: considering a natural increase of $2.5 \%$ per year, mortality between birth and 5 years was $22.4 \%$ for Nasca and $25.1 \%$ for Wari. Infant mortality rate was 33\% for Nasca and $105 \%$ for Wari. Death percentages in all the age groups increased from Nasca to Wari phase. The paleodemographic study of the Nasca valley skeletal populations confirmed the archaeological hypothesis of worse conditions of the Wari population in comparison with the previous Nasca people (Drusini et al., 2001). All teeth belonging to the Andes (Proyecto Condesuyos, Tablada de Lurín (Proyecto Loma de Lesix) were stored in the Arequipa University Museum.

\section{RESULTS AND DISCUSSION}

We have identified 20 lower first permanent molars with supernumerary distolingual third roots (3RM1) in the Easter Island sample. In the Peruvian sample, we found $7.8 \%$ of 3 RLM1 at Nasca, $1.2 \%$ at Tablada de Lurin, and $9 \%$ at Condesuyos. Supernumerary distolingual roots can occur on any of the three lower permanent molars, but they are much more common on M1 than on M3, and appear more frequently on these two molars than on M2 (Tratman, 1938, 1950; Pedersen, 1949; Turner, 1971; Loh, 1990); according to all investigators, it is extremely rare on M2. The distolingual root also occurs in low frequency on the deciduous first and second molars (Tratman, 1938; Jørgensen, 1956): Tratman (1950) says that if it occurs on $\mathrm{dm} 2$ it may be expected on M1. There are no deciduous molars in the present sample. Of all lower molars, 3RM1 is present on M1 in much greater frequency than on M2 or M3, which led Turner (1971:233) to suggest that the permanent first molar is the location for a "field-affecting gene(s)" controlling the development of the third root. To our knowledge, there is no study of the mode of inheritance of 3RM1 but because of its diachronic and population variation, Turner and Benjamin (n.d.) suggest that there is a "substantial genetic component in occurrence and expression."

The incidence of the distolingual root on M1 in the sexes as well as its presence on the left or right side is variable in the populations investigated to date (Tratman, 1938, 1950; Turner, 1971; Turner and Benjamin, n.d.; Loh, 1990). Moreover, some studies suggest it is a sexlinked dominant character (Tratman, 1938; Curzon and 


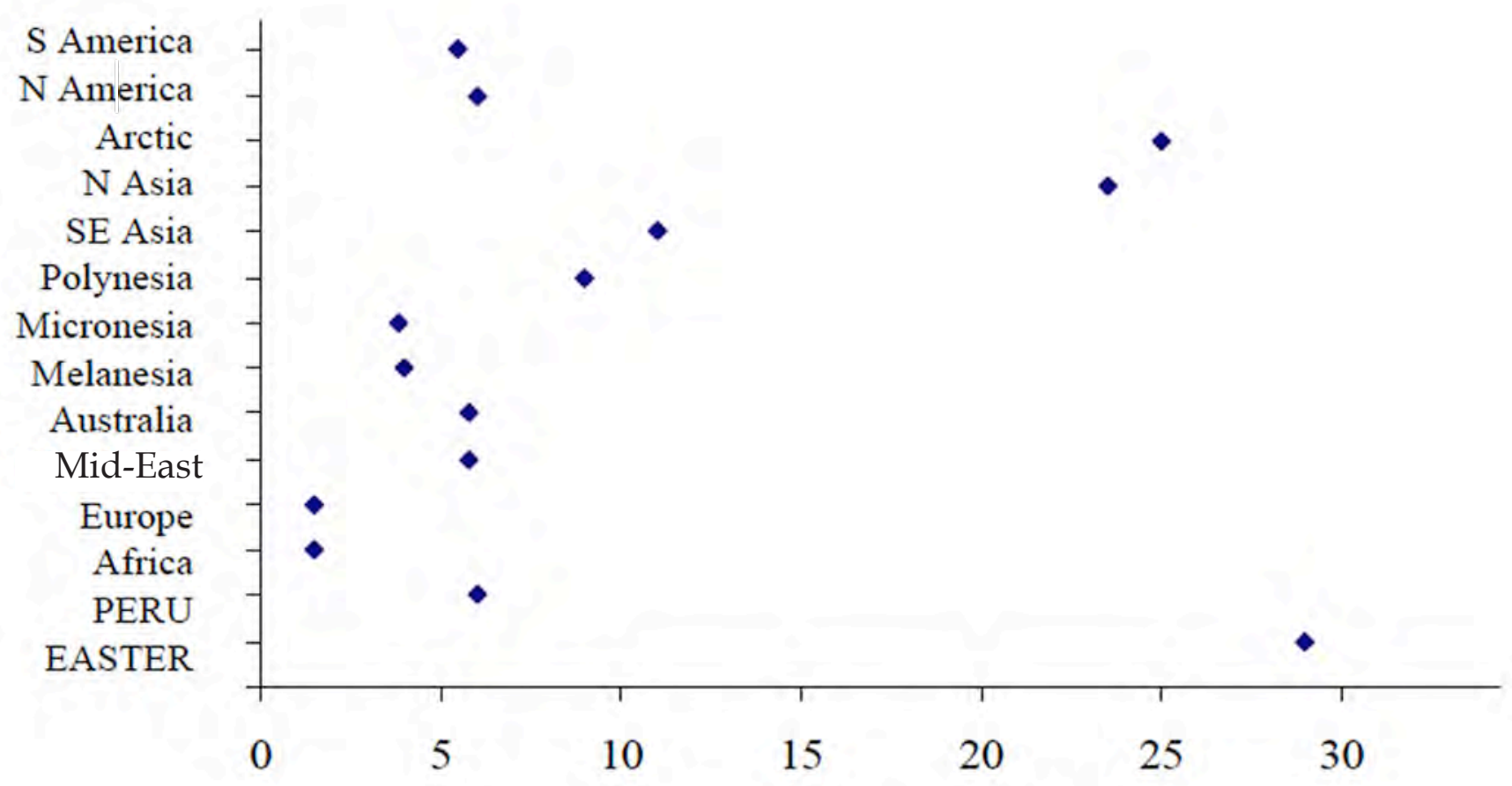

Fig. 2. Mean and range percentage of 3-rooted lower first molars (modified from Turner and Benjamin, n.d.).

Curzon, 1971; Hochstetter, 1971), while others claim that there is no sex predilection (Walker and Quackenbush, 1985; Loh, 1990). The third root originates from the lingual side of the distal root below the cervical border and appears to be a true supernumerary root in the Easter Island sample, which is in accord with Tratman (1938, 1950) and Turner's (1971) findings regarding the development of the distolingual root. The third root tends to be slender, somewhat conical in shape, divergent, and usually curved at the apical end towards the longer distal root; it is rarely as long as the distal root, although it varies in length and form. According to Tratman (1950) in his Asian sample, the distolingual root is only present on M1 when there are five cusps. Turner (1971) does not mention the number of cusps present on 3RMls. In the Easter Island sample there is one 3RM1 with only four cusps. When the extra root is present on M3 there may be a reduction in the number of cusps, however the four cusped three-rooted molar just mentioned cannot be a third molar since there are two well formed contact areas on the mesial and distal surfaces of the crown. The extra root rarely appears on M2 but when it does, the crown is well formed and the fifth cusp is well developed.

The precontact Easter Island sample contained 20 lower molars with an extra root. As mentioned, we identified $70 \mathrm{Mls}, 62 \mathrm{M} 2 \mathrm{~s}$ and $40 \mathrm{M} 3 \mathrm{~s}$. This equates to $29 \%$ with 3RM1. If we add M2s to M1s the figure drops to $15 \%$ and if we add M3s to M1s it is $18 \%$. These are all high percentages for Polynesia, and we believe the more correct figure is around $29 \%$. It is obvious that precontact Easter Islanders, based on the present sample, had a high incidence for Polynesia of 3RM1s. The 29\% frequency for 3RM1 is considerably beyond the range for Polynesia except the sample of Easter Island skulls (of uncertain antiquity) that Turner and Benjamin (n.d.) studied, which had 21.8\% 3RM1. It appears that Easter Islanders had, and still have, one of the highest frequencies of 3RM1 of all Polynesian populations studied to date.

The percentages of 3RM1 frequencies shown in Fig. 2 for the major cultural areas in the Pacific are the averages from Turner and Benjamin (n.d.). Within each of these areas the percentages for several different islands are shown and unfortunately, there are still many gaps in our information regarding the incidence of 3RM1s for many of the islands: there appears to be no west-to-east cline in the distribution of 3RM1. Rather, the frequencies are variable from island to island and tend to support the thesis proposed here of the importance of the founder principle and its effect on subsequent generations of new populations with few colonizers. In southern China and Southeast Asia, the average frequency of 3RM1 is 10 to $15 \%$, although in historic samples from Sumatra and Java the frequencies are $23 \%$ and $16 \%$, respectively. In Australia, the average is $10 \%$ and represents samples from various parts of the continent. In Micronesia (3\%) and Melanesia (3\%) the condition is virtually absent, in fact, it has not been found in New Guinea but is present in nearby New Britain (5\%). In Fiji, the most easterly 
group of islands in Melanesia, 3RMls have the highest incidence in all of Melanesia, about $10 \%$. This higher frequency may be associated with the stronger ethnic, cultural, and linguistic concordance between Fiji and Polynesia.

The three-rooted lower first permanent molars are found in a montage of frequencies in Polynesia. The trait is apparently absent on some islands (Samoa, Gambier, New Zealand/Chatham Islands, and the Tuamotu Islands [all historic samples], and a late prehistoric sample from the Marquesas islands). On Tahiti (historic) it is $10 \%$, Mokapu (prehistoric) it is 12\%, Society Islands (historic) it is $8 \%$, Cook Islands (historic) it is $9 \%$, and in the Loyalty Islands (historic) it is $7 \%$. In a second sample of prehistoric-to-recent Marquesans, Turner and Benjamin (n.d.) report an incidence of $2.7 \%$, while on Easter Island (uncertain of antiquity) it is $21.8 \%$. It is interesting to note that a relatively high incidence of 3RM1 - comparable to Easter Island - is found routinely in the Arctic (average $=30 \%$ ) and Northern Asia (average $=25 \%$ ). In several of the indigenous populations of both North and South America frequencies ranging into the teens and low twenties are present even though the averages are 8 and $7 \%$ for the two regions.

It seems likely that the discovery of Easter Island was an accidental event from which return voyages were unlikely (Houghton, 1996). Such migration patterns are ideal for the operations of founder effect, genetic bottlenecks, and genetic drift. It is well known that such random factors can produce alteration of gene frequencies, especially in small populations. Also, it was not necessary for such small groups to have differed a great deal from the larger populations from which they became detached because when a new closed population is formed it can develop a unique genetic system of its own. Once established these genetic systems tend to persist. Because of this type of population deployment throughout both Near and Remote Oceania, there is the present mosaic pattern of genetic complexes, for example the variable incidence of 3RM1 or the variation of haplotype B, we find represented today in the Pacific.

\section{CONCLUSION}

Except for the continent of Australia and the island of New Guinea, the Pacific Islands only started to be occupied some 5,000 years ago; some of the more easterly Polynesian islands little more than a 1,000 years ago. It is generally agreed that the major direction of migration has been from west to east, although there have been dissenting views from time to time (Heyerdahl, 1952; Bellwood, 1987; Terrell, 1990; Irwin, 1994). The mosaic distribution of 3RMls in the Pacific islands is, in our opinion, the result of many genetic bottlenecks, which the settlers went through as they crossed the Pacific Ocean. The survivors of a bottleneck may have a very different genetic composition from the population prior to the bottleneck, and in turn may become the settlers (founder effect) on another island. Such chance events result in genetic drift and have undoubtedly played important roles in regulating the past and present mosaic distribution of 3RMls in these insular populations, an hypothesis first enunciated by Turner and Benjamin (n.d.).

Note: This paper is dedicated to the memory of Daris R. Swindler (August 13, 1925 - December 6, 2007).

\section{REFERENCES CITED}

Bahn P. 1993. The history of human settlement on Rapanui. In: Fischer SR, ed. Easter Island studies. Oxford: Oxbow Monograph 32:53-55.

Bahn P, Flenley J. 1992. Easter Island, earth island. London: Thames \& Hudson.

Bellwood P. 1987. The Polynesians: prehistory of an island people. London: Thames \& Hudson.

Curzon MEJ, Curzon AJ. 1971. Three-rooted mandibular molars in the Keewatin Eskimo. Can Dent Assoc 37:71-72.

Drusini AG, Carrara N, Orefici G, Rippa Bonati M. 2001. Palaeodemography of the Nasca valley: reconstruction of the human ecology in the southern Peruvian coast. Homo 52:157-172.

Finney, B. 1993. Voyaging and isolation in Rapa Nui prehistory. Rapa Nuì Journal 7:1-6.

Heyerdahl T. 1952. American Indìns in the Pacific. London: Allen and Unwin.

Hochstetter RL. 1975. Incidence of trifurcated mandibular first permanent molars in the population of Guam. J Dent Res 54:1098.

Houghton P. 1996. People of the great ccean: aspects of human biology of the early Pacific. Cambridge: Cambridge University Press.

Irwin G. 1994. The prehistoric exploration and colonization of the Pacific. Cambridge: Cambridge University Press.

Jones S. 1994. The peopling of the Pacific. In: Jones S, Martin R, Pilbeam D, eds. The Cambridge encyclopedia of human evolution. Cambridge: Cambridge University Press, p 394.

Jørgensen K. 1956. The deciduous dentition. Acta Odont Scand (supplement 20) 14:7-191.

Kirch PV. 1984. The evolution of Polynesian chiefdoms. Cambridge: Cambridge University Press.

Loh HS. 1990. Incidence and features of three-rooted permanent mandibular molars. Austral Dent J 35:434-437.

Ming-Gene Tu, Chi-Cheng Tsai, Ming-Jia Jou, Lie Chen, Yu-Fang Chang, San-Yue Chen, Hui-Wen Cheng. 2007. Prevalence of three-rooted mandibular first molars among Taiwanese individuals. J Endodontics 33:1163-1166.

Orefici G, Drusini AG. 1993. Analysis of the context 
of burials in the Plaza of Ahu Tongariki. Paper presented at the International Conference on Easter Island Research, University of Wyoming. (Abst. p. 30).

Pedersen PO. 1949. The East Greenland Eskimo dentition: numerical variations and anatomy, a contribution to comparative ethnic odontography. Copenhagen: Meddelelser om Gronland.

Taylor AE. 1899. Variations in the human tooth-form as met with in isolated teeth. J Anat Physiol 33:268-272.

Terrell J. 1990. Prehistory in Pacific islands. Cambridge: Cambridge University Press.

Tratman EK. 1938. Three-rooted lower molars in man and their racial distribution. Br Dent J 64:264-274.

Tratman EK. 1950. Comparison of teeth of people of Indo-European racial stock with the Mongoloid racial stock. Dental Record 70:31-53, 63-68.
Turner CG II. 1971. Three-rooted mandibular first permanent molars and the question of American Indian origins. Am J Phys Anthropol 34:229-242.

Turner CG II, Benjamin O. n.d.. World variation in three-rooted lower first permanent molars. Paper read at the 8th International Symposium on Dental Morphology, Jerusalem, Israel, 1990.

Van Tilburg J. 1994. Easter Island: archaeology, ecology, and culture. Washington, DC: Smithsonian Institution Press.

Walker T, Quackenbush LE. 1985. Three-rooted lower first permanent molars in Hong-Kong Chinese. $\mathrm{Br}$ Dent J 159:298-299. 